\title{
EMPATHY CARE TRAINING UNTUK MENINGKATKAN PERILAKU MEMAAFKAN PADA REMAJA AKHIR
}

\section{EMPATHY CARE TRAINING FOR INCREASE FORGIVENESS ON LAST-ADOLESCENSE}

\author{
Rifka Annisa \\ Anggia K.E. Marettih \\ Fakultas Psikologi Universitas Islam Negeri Sultan Syarif Kasim Pekanbaru \\ Email: rifkaannisacha23@gmail.com
}

\begin{abstract}
ABSTARCT
This study aimed to have know influence empathy care training for increase forgiveness on lastadolescense. This research experiment is true experiment use two group pretest-posttest control group design between subject. Subject of the research are 16 last-adolescence which 8 into experiment group and 8 into control group. The data were collected by using forgiveness scale (Nashori, 2012). The result of Mann Whitney U Test analiysis showed value Asymp. Sig. (2 tailed) 0,020 $(p<0.05)$ with value Z score 2.329. It is mean, empathy care training can increase forgiveness to last-adolescense. The result of Wilcoxon Signed Rank Test on experiment group showed value Asymp. Sig. (1 tailed) 0,046 ( $p<0,05)$ it is mean there is different at pretest-posttest score. Empathy care training can help last-adolescense increase empathy that so able to describe reflect on position other people guilty also chosen to make a peace with guilty individu and then can increase forgiveness.
\end{abstract}

Keyword: forgiveness, empathy care training, last-adolescense.

\begin{abstract}
ABSTRAK
Tujuan penelitian ini adalah untuk mengetahui pengaruh empathy care training dalam meningkatkan perilaku memaafkan pada remaja akhir. Jenis penelitian eksperimen murni dengan desain between subject randomized two group pretest-posttest control group design. Subjek berjumlah 16 orang yang dikelompokkan secara acak menjadi 8 orang kelompok eksperimen dan 8 orang kelompok kontrol. Data penelitian dikumpulkan melalui skala perilaku memaafkan oleh Nashori (2012). Dari hasil analisis Mann Whitney U Test di peroleh nilai Asymp. Sig. (2 tailed) sebesar 0,020 $(p<0,05)$ dengan nilai Z Score sebesar -2.329. Artinya, empathy care training dapat meningkatkan perilaku memaafkan pada remaja akhir. Dari hasil analisis Wilcoxon Signed Rank Test pada kelompok eksperimen diperoleh nilai Asymp. Sig. (1 tailed) sebesar 0,046 $(p<0,05)$ yang artinya terdapat perbedaan antar skor prates dengan pascates pada kelompok eksperimen. Empathy care training dapat membantu remaja meningkatkan empati sehingga mampu membayangkan jika berada di posisi individu yang bersalah serta lebih memilih untuk berdamai dengan individu yang bersalah sehingga dapat meningkatkan perilaku memaafkan pada remaja.
\end{abstract}

Kata kunci: Perilaku Memaafkan, Empati, Empathy Care Training, Remaja Akhir. 
Dalam melakukan hubungan sosial, individu kadang-kadang berbuat salah kepada individu lain. Pada sisi lain, individu tentu pernah mengalami perlakuan dan situasi yang mengecewakan atau menyakitkan. Remaja adalah salah satu masa yang dilewati oleh individu. Sebagai individu yang beranjak dewasa, remaja juga melakukan interaksi dengan individu lain untuk melakukan hubungan sosial demi kelangsungan dalam menyesuaikan diri dengan lingkungan.

Hurlock (2011) membagi masa remaja menjadi masa remaja awal dan remaja akhir, sedangkan pemisah antara usia remaja awal dan akhir terletak pada usia 17 tahun hingga usia awal dewasa ketika remaja sudah hampir memasuki dunia kerja orang dewasa. Sementara usia dewasa awal, menurut Hurlock, berada pada usia 21 tahun, sehingga pada penelitian ini peneliti menggunakan usia remaja akhir dengan batas usia dari 17 tahun hingga 21 tahun.

Hurlock (2011) menyatakan bahwa keadaan emosi remaja berada pada periode badai dan tekanan (storm and stress), yaitu suatu masa di mana ketegangan emosi meninggi sebagai akibat dari perubahan fisik dan kelenjar. Meningginya emosi remaja karena remaja berada di bawah tekanan sosial, teman sebaya, dan menghadapi kondisi serta harapan baru. Hal ini menyebabkan remaja mengalami kegagalan dalam menyelesaikan masalah yang dihadapinya. Oleh sebab itu masa remaja sering dikatakan sebagai usia bermasalah. Masalah-masalah yang terjadi pada remaja sering menjadi masalah yang sulit untuk diatasi juga dikarenakan para remaja merasa mandiri dan memiliki teman sebaya yang lebih mengerti akan dirinya sehingga mereka ingin mengatasi masalahnya sendiri dan menolak bantuan keluarga, orangtua dan guru. Namun, hubungan pertemanan sebaya ini tidak berlangsung lama dan harmonis, karena secara emosi setiap remaja memiliki sifat egosentris yang tinggi dan ingin menang sendiri sehingga memicu terjadinya konflik selama periode masa remaja. Tidak sedikit dari hubungan pertemanan remaja berakhir pada konflik, kekecewaan, ataupun menyakitkan hati.

Hurlock (2011) mengungkapkan sebagai pihak yang sudah beranjak ke masa dewasa remaja dituntut memiliki kemampuan untuk dapat mereduksi dan mengelola emosi, mampu menunjukkan emosio yang stabil, dan mampu menggambarkan berbagai situasi dan rangsangan yang dapat menimbulkan reaksi emosional. Salah satu caranya adalah 
dengan membicarakan masalah atau pertikaian yang terjadi dengan individu lain, sehingga remaja tidak lagi menyimpan perasaan sakit dari perasaan sendiri, mampu melepaskan semua amarah, dan tidak lagi mempunyai perasaan untuk membalas semua sakit hati, sehingga dapat membangun kembali relasi yang baik dengan individu yang bersalah yang ditunjukkan dengan perilaku memaafkan.

Penyelesaian konflik antar pribadi dan merajut hubungan yang telah retak bukanlah hal yang sederhana. Memaafkan merupakan cara yang efektif untuk mengatasi permasalahan antar individu karena di dalam memaafkan melibatkan empat proses, yaitu pengetahuan, pemahaman, memberikan kesempatan kepada individu yang bersalah untuk memperbaikinya, dan berakhir pada memberikan maaf (Hargrave, 1994). Memaafkan dapat diartikan sebagai suatu kondisi saat remaja telah siap untuk menerima dan melepaskan rasa sakit hati atau kekecewaan yang dialami. Hal ini ditandai oleh adanya keikhlasan hati untuk dapat melepaskan semua perasaan terluka, sakit hati, meninggalkan kemarahan dan balas dendam, sehingga dapat mencapai suatu perdamaian dan membina kembali hubungan dengan individu yang bersalah. Namun, ada kalanya memaafkan pada remaja sering kali terjadi hanya sekedar memaafkan dari mulut saja tanpa memaafkan setulus hati. Hal ini karena periode dan kondisi emosi remaja yang masih labil. Remaja mudah marah dan mudah memaafkan juga, tetapi banyak remaja yang tidak memahami makna memaafkan yang sebenarnya sehingga mudah kembali mengalami konflik.

Berdasarkan American Psychological Association (2006), diketahui memaafkan adalah suatu proses tindakan sebagai upaya yang dilakukan seseorang untuk melibatkan diri dengan mengubah emosi negatif dan menunjukkan perilaku pengampunan dan tidak membalas kepada individu yang menyakiti. Perilaku memaafkan itu sendiri dapat dibedakan dari melupakan, membalas orang lain dengan setimpal dengan perbuatannya atau rekonsiliasi. McCullough, Rachal, dan Worthington (1997) mengungkapkan bahwa perilaku memaafkan adalah konsep dasar yang menghambat seseorang untuk tetap mempertahankan permusuhan maupun upaya balas dendam. Perilaku memaafkan pada akhirnya akan meningkatkan motivasi pada diri seseorang untuk melakukan konsiliasi yang bersifat lebih konstruktif bagi pihak yang bertikai. Sementara itu Nashori (2012) mengungkapkan bahwa pemaafan (for- 
giveness) adalah kesediaan untuk meninggalkan hal-hal yang tidak menyenangkan yang bersumber dari hubungan interpersonal dengan orang lain dan menumbuhkembangkan pikiran, perasaan, dan hubungan interpersonal yang positif dengan orang lain yang melakukan pelanggaran secara tidak adil. Nashori membagi pemaafan dalam tiga dimensi, yaitu emosi, kognisi, dan interpersonal. Disebutkan oleh Nashori (2011) dan Nashori, Iskandar, Setiono, dan Siswadi (2013), dimensi emosi meliputi indikator-indikator (a) Meninggalkan perasaan marah, sakit hati, benci, (b) Mampu mengontrol emosi saat diperlakukan tidak menyenangkan, (c) Perasaan iba dan kasih sayang terhadap pelaku, dan (d) Perasaan nyaman ketika berinteraksi dengan pelaku. Dimensi kognisi meliputi indikator-indikator (a) Meninggalkan penilaian negatif terhadap pelaku, (b) Memiliki penjelasan nalar atas perlakuan yang menyakitkan, (c) Memiliki pandangan yang berimbang terhadap pelaku. Selanjutnya, dimensi interpersonal meliputi indikator-indikator (a) Meninggalkan perilaku atau perkataan yang menyakitkan terhadap pelaku, (b) Meninggalkan keinginan balas dendam, (c) Meninggalkan perilaku acuh tak acuh, (d) Meninggalkan perilaku menghindar, (e) Upaya konsiliasi/rekon- siliasi hubungan, (f) Motivasi kebaikan atau kemurahan hati, dan (g) Musyawarah dengan pihak yang pernah jadi pelaku.

Dalam memaafkan idealnya sikap dan perasaan negatif digantikan oleh sikap dan perasaan positif, namun pada kenyataannya hal ini tidak mudah dilakukan, apalagi secara cepat. Selalu ada persoalan psikologis di antara dua pihak yang pernah mengalami keretakan hubungan akibat suatu kesalahan. Oleh karena itu, memaafkan sejatinya bukan melupakan kesalahan individu yang berbuat salah, tetapi membiarkan perasaan negatif menjadi sebuah pemahaman untuk berubah ke perasaan positif (Doverspike, 2001).

Untuk sampai kepada tahap perilaku atau tindakan memaafkan, individu melibatkan aspek kognitif dan afektif. Salah satu aspek afektif dan kognitif yang berpengaruh terhadap perilaku memaafkan adalah empati. Berdasarkan hasil penelitian yang telah dilakukan oleh Kurniati (2009) ditemukan bahwa terdapat hubungan yang positif signifikan antara empati dan memaafkan. Studi yang mengaitkan dimensi pengambilan sudut pandang dan kepedulian empatik menunjukkan korelasi yang signifikan berarah positif dengan memaafkan. Menurut Carre, Stefaniak, Richard, Ben- 
salah, dan D'Ambrosio (2013), empati merupakan kemampuan memahami pandangan dan perasaan orang lain serta kemampuan merasakan emosi dan memahami penyebab terjadinya emosi yang dirasakan orang lain. Melalui empati remaja dapat memahami, merasakan, menghayati orang lain karena dalam proses empati ini berlangsung proses pengertian dan perasaan yang dinyatakan dalam bentuk hubungan antar pribadi. Riess, Kelley, Bailey, Dunn, dan Phillips (2011) mengemukakan empati adalah kemampuan individu yang melibatkan proses kognitif dan afektif yang memungkinkan individu untuk menempatkan diri berada diposisi dan emosional orang lain. Kemampuan empati tersebut berupa respon emosional yang sangat menyerupai respon emosional orang lain tanpa individu kehilangan kontrol dirinya (Taufik, 2012).

Pada remaja akhir, kemampuan empati merupakan kemampuan yang efektif dalam memaafkan atau memberi maaf kepada orang lain yang telah membuat luka, menyakiti, atau mengecewakan. Hasil penelitian Asih dan Pratiwi (2010) mengungkapkan bahwa empati dapat mendorong individu khususnya remaja untuk melakukan perilaku prososial. Selain itu empati juga memi- liki hubungan yang signifikan dengan kematangan emosi untuk prilaku prososial pada remaja. Kematangan emosi yang dimaksud adalah remaja mampu mengelola emosi dengan baik yang ditunjukkan tidak membalas rasa sakit hati kepada individu yang telah menyakiti. Selain itu, berdasarkan hasil penelitian yang dilakukan Untari (2014) diketahui bahwa terdapat sumbangan efektif yang diberikan variabel empati terhadap sikap pemaaf. Hal ini membuktikan bahwa empati memengaruhi pemaafan pada remaja putri yang mengalami kekerasan dalam berpacaran. Dalam penelitian ini, peneliti menghubungkan empati dan perilaku memaafkan.

Remaja yang memiliki kemampuan empati yang tinggi juga berarti memiliki kemampuan yang tinggi dalam memahami perasaan individu lain, berpikir dan merasakan keadaan individu lain. Kaitannya dengan perilaku memaafkan, remaja akhir yang memiliki empati akan mampu memahami, merasakan, menghayati perasaan orang lain karena dalam proses empati ini berlangsung proses pengertian dan perasaan yang dinyatakan dalam bentuk hubungan antar pribadi. Hal tersebut akan mendorong remaja dengan mudah untuk melepaskan rasa mengecewakan, menyakitkan, 
dan perasaan luka yang disebabkan oleh individu lain yang berujung pada memaafkan atau memberi maaf. Karena remaja yang empati juga akan merasakan keadaan individu yang menyakitinya bila seandainya tidak dimaafkan. Dalam sikap empati remaja, juga dipengaruhi oleh kesadaran individu untuk lebih memperbaiki hubungan yang telah rusak.

Menurut Borba (Taufik 2012), setiap individu mempunyai kemampuan yang berbeda-beda dalam berempati. Pada dasarnya empati muncul secara alami sejak masih bayi, namun belum ada jaminan yang pasti bahwa kemampuan empati ini akan terus berkembang dengan baik. Dengan begitu kemampuan pada empati juga dapat ditingkatkan atau dikembangkan. Jika remaja akhir memiliki kemampuan empati yang tinggi, maka hal itu juga akan meningkatkan perilaku memaafkan.

Salah satu cara yang dapat meningkatkan perilaku memaafkan pada remaja akhir adalah dengan Emphaty Care Training. Care dalam artian penelitian ini adalah suatu sikap rasa peduli, hormat, menghargai orang lain, dan mengerti perasaan orang lain (ichapiiz.blogspot.com/2012). Tentu saja maksud dan arti care ini memiliki artian yang sama dengan empati, karena caring merupakan perpaduan antara pengetahuan biofisik dengan pengetahuan mengenai perilaku orang lain. Emphaty care training berupa kegiatan pelatihan yang berisi rangkaian sesi berupa pemberian materi dan pengetahuan dengan metode seminar. Selain pemberian materi terkait empati dan perilaku memaafkan, dalam pelatihan ini remaja akhir juga akan bermain peran sehingga emosi remaja akhir dapat terlibat langsung dan kognitif remaja dapat berfikir bagaimana hubungan empati dengan perilaku memaafkan dan mengaplikasikannya dalam bentuk perilaku mudah memaafkan. Pelatihan ini mengacu pada aspek-aspek empati oleh Davis (1980), yaitu perspective taking, fantasy, emphatic concern, and personal distress. Emphaty care training (selanjutnya disingkat ECT) ini dilakukan dengan tujuan sebagai pelatihan yang di dalamnya terdapat berbagai kegiatan yang mengacu pada aspekaspek empati. Oleh karena itu, adanya ECT dapat membantu remaja akhir atau mahasiswa yang berada pada usia remaja akhir untuk meningkatkan kemampuan empati sehingga akan berdampak dengan meningkatnya perilaku memaafkan.

Dari penjelasan atau pemaparan latar belakang yang telah diuraikan ECT dinilai penting untuk membantu remaja 
akhir dalam memahami kondisi atau perasaan orang lain, menempatkan posisi diri di posisi orang lain sehingga mendorong remaja akhir untuk dapat memaafkan dengan tulus. Adanya ECT ini diharapkan dapat meningkatkan kemampuan empati pada remaja akhir. Dengan begitu remaja akhir juga akan dengan mudah menggantikan emosi negatif ke emosi positif kepada individu yang menyakitinya sehingga mampu memaafkan tidak hanya sekedar di mulut saja tetapi dengan setulus hati untuk mencapai kepuasan hidup. Untuk itu pada penelitian ini, penulis ingin melihat pengaruh emphaty care training untuk meningkatkan perilaku memaafkan pada remaja akhir.

Berdasarkan penjelasan di atas, dapat dirumuskan hipotesis penelitian, yaitu ada pengaruh emphaty care training dalam meningkatkan perilaku memaaafkan pada remaja akhir.

\section{METODE PENELITIAN}

\section{Desain Eksperimen}

Penelitian ini menggunakan true experiment (eksperimen murni). Digunakannya eksperimen murni dalam penelitian ini karena pengelompokan subjek dilakukan secara random dan menjadikan kelompok kontrol sebagai kelompok pembanding (Latipun, 2004). Desain penelitian yang digunakan dalam penelitian ini adalah between subject randomized pretest-posttest control group design. Disebut desain between subject karena pengaruh VB terhadap VT diketahui dari perbedaan skor VT antara kelompok-kelompok subjek, sedangkan Randomized dilakukan untuk membagi subjek ke dalam kelompok eksperimen dan kelompok kontrol dari sampel yang telah setara. Penelitian ini terdiri atas kelompok yang diberi perlakuan yaitu kelompok eksperimen dan kelompok tanpa perlakuan yaitu kelompok kontrol. Prates dilakukan sebelum mendapatkan perlakuan dan pascates dilakukan setelah mendapatkan perlakuan (Latipun, 2004).

\section{Subjek Penelitian}

Populasi dalam penelitian ini adalah seluruh mahasiswa-mahasiswi UIN Suska Riau yang berada pada rentang usia remaja akhir. Adapun kriteria yang akan menjadi populasi dalam penelitian ini adalah (a) Mahasiswa-mahasiswi yang berada pada usia remaja akhir berdasarkan Hurlock (2011), yaitu usia 17-21 tahun, (b) Memiliki skor perilaku memaafkan yang sedang hingga sangat rendah yang ditunjukkan dari hasil skala perilaku 
memaafkan dari Nashori (2012) melalui screening, dan (c) Memiliki seorang atau lebih teman dekat yang dapat dilihat dari tulisan essay calon subjek

Subjek penelitian ini adalah calon subjek yang telah memenuhi kriteria sebagai subjek penelitian yang telah terjaring melalui proses screening. Dari 23 orang calon subjek yang di screening, ada 16 orang yang sesuai kriteria untuk menjadi subjek penelitian. Sebanyak 16 orang tersebut dibagi secara acak 8 orang untuk kelompok eksperimen dan 8 orang untuk kelompok kontrol.

\section{Teknik Pengumpulan Data}

Dalam penelitian ini untuk mengukur perilaku memaafkan pada remaja akhir digunakan skala perilaku memaafkan. Skala perilaku memaafkan yang digunakan merupakan modifikasi dari skala Nashori (2012) yang disusun berdasarkan model skala likert dengan menggunakan empat alternatif pilihan jawaban, yaitu SL (Selalu), SR (Sering), KD (Kadang-kadang), TP (Tidak pernah).

Berdasarkan uji coba alat ukur terhadap 272 orang subjek pada skala perilaku memaafkan dari 27 aitem diperoleh 22 aitem yang sahih dan 5 aitem yang gugur dengan koefisien korelasi daya beda aitem $>0,30$ dengan bantuan komputasi program SPSS 18.
Nilai reliabilitas menunjukkan bahwa skala perilaku memaafkan memiliki koefisien reliabilitas yang tinggi karena mendekati angka 1,00, yaitu 0,86 sehingga dapat digunakan sebagai alat ukur dalam penelitian ini. Sementara itu validasi modul eksperimen dilakukan oleh beberapa validator yang merupakan dosen yang berpengalaman dan ahli dalam penelitian eksperimen. Selain itu, dalam penelitian ini peneliti melakukan validitas internal dan eksternal.

\section{Prosedur Intervensi}

Empathy care training (ECT) adalah suatu bentuk kegiatan pelatihan empati yang dirancang untuk meningkatkan empati pada remaja akhir. ECT dilakukan dengan metode seminar yang didalamnya terdapat pemberian experience sheet, penayangan film serta game. ECT ini dirancang berdasarkan aspekaspek empati oleh Davis (1980) yaitu perspective taking, fantasy, empathic concern, dan personal distress.

ECT merupakan pelatihan yang bertujuan untuk meningkatkan empati yang akan berpengaruh terhadap perilaku memaafkan. Dalam penelitian ini sasaran dai ECT adalah remaja akhir. Empati dianggap sebagai komponen utama dalam memaafkan, karena memaafkan erat kaitannya dengan prilaku pro- 
sosial. Beberapa peneliti menetapkan bahwa di dalam ECT di dalamnya perilaku prososial dan memahami perasaan individu lain. Adapun komponen dari ECT dengan menggunakan pendekatan empati, yaitu (a) Pelatihan persepsi yang melibatkan kognitif dan respon emosi untuk menilai baik individu lain dan menjaga hubungan interpersonal. (b) Pelatihan mengenali dan fokus pada perasaan orang lain, karena jika individu telah mampu mengenali perasaan sendiri akan dengan mudah bagi individu untuk mengenali dan memahami perasaan orang lain. (c) Fokus pada persamaan antar perasaan sendiri dan perasaan orang lain. Pada komponen ini pelatihan berfokus bagaimana individu mampu merasakan adanya perasaan yang sama antara dirinya dan individu yang telah menyakitinya, sehingga akan sangat efektif untuk memunculkan empati.

ECT terdiri atas 5 sesi, yaitu knowing, think and fell, I and my own, I care to other, dan personal distress. Sesi I, yaitu knowing, berisi pengenalan ECT dan perilaku memaafkan. Dalam sesi ini output yang hendak dicapai adalah Remaja akhir dituntut untuk mampu mengenali semua hal-hal yang berkaian dengan perilaku memaafkan. Termasuk menge-nai mengetahui perasaan terluka/ menyakitkan, benteng diri untuk menyembuhkan luka, mengetahui bagaimana memaafkan yang sesungguhnya. Sesi ini berlangsung selama 30 menit.

Sesi II, yaitu think and fell, berisi pembahasan mengenai perspective taking. Output yang hendak dicapai dalam sesi ini adalah kemampuan remaja akhir untuk berfikir dan merasakan di posisi orang lain. Komponen ini mencakup: mengenali perasaan sendiri, mengenali perasaan orang lain, menganalisis kesalahan sendiri dan orang lain, menganalisis perasaan sendiri dan orang lain. Sesi ini berlangsung selama 35 menit.

Sesi III, yaitu I and my own, berisi pembahasan mengenai imagery. Sesi ini untuk mencapai kemampuan remaja akhir untuk mengubah diri secara imajinatif untuk memahami perasaan orang lain, di dalamnya mencakup: Mengandaikan karakter imajinasi dengan diri sendiri, kontrol emosi, dan kesadaran diri. Sesi ini diberikan selama 35 menit.

Sesi IV, yaitu I care to other, berisi pembahasan mengenai empathic concern. Output yang hendak dicapai dalam sesi ini adalah Kemampuan remaja akhir untuk memiliki perasaan simpati kepada orang lain. Aspek ini juga mencakup: Komunikasi interpersonal, sikap prihatin, 
sikap simpati. Sesi ini diberikan selama 30 menit.

Sesi V, yaitu personal distress, berisi pembahasan mengenai kecemasan individu pada diri sendiri terhadap hubungan interpersonalnya dengan individu yang bersalah. Output yang hendak dicapai dalam sesi ini adalah kemampuan remaja akhir untuk menghadapi kecemasan yang berorientasi pada diri sendiri terhadap kualitas interpersonal. Di dalam aspek ini mencakup: Mengelola emosi dan mengelola perasaan. Sesi ini berlangsung selama 30 menit.

Pada setiap sesi, subjek diminta untuk merefleksikan kembali apa yang telah diberikan oleh fasilitator dengan menuliskannya ke dalam kertas yang telah disediakan. Selain itu, subjek juga diminta untuk bermain game yang telah dirancang peneliti bertujuan sebagai aplikasi dari materi yang akan atau telah diberikan oleh fasilitator.

\section{Teknik Analisis Data}

Teknik analisis data yang digunakan untuk menguji hipotesis dalam penelitian ini adalah teknik analisis independent sample t-test dengan teknik Mann-Whitney U Test. Mann-whitney $U$ Test bertujuan untuk melihat analisis dua kelompok yang independen. Analisis dilakukan pada kelompok eksperimen dan kelompok kontrol. Analisis data dalam penelitian ini menggunakan program SPSS (Statistical of Package for Social Science) 18 for windows. Selain itu, untuk melihat perbedaan kedua kelompok pada pengukuran prates-pascates dalam penelitian ini digunakan analisis Wilcoxon Signed Rank Test. Sumber data analisis Wilcoxon Signed Ranks Test adalah skor prates dan pascates kelompok eksperimen dan kelompok kontrol.

\section{HASIL PENELITIAN}

Sebelum dilakukannya analisis statistik terkait proses pengukuran hasil eksperimen yang telah dilakukan, dibutuhkan acuan normatif yang akan memudahkan pengguna memahami hasil pengukuran (Azwar, 2013). Untuk memudahkan hasil pengukuran, peneliti membuat kategorisasi pada skala perilaku memaafkan. Tujuan kategorisasi adalah untuk menempatkan individu ke dalam kelompok-kelompok yang posisinya berjenjang menurut suatu kontinum berdasarkan atribut yang diukur (Azwar, 2013). Pengkategorisasian sama dengan memberikan ranking dari skor yang tertinggi hingga ke terendah, melalui ranking dapat membantu peneliti untuk membedakan skor tiap subjek (Field, 
2009). Pengkategorisasian subjek penelitian dikelompokkan menjadi lima kategorisasi, yaitu sangat rendah, rendah, sedang, tinggi, dan sangat tinggi dengan ketentuan sebagai berikut:

Tabel 1. Norma Kategorisasi

\begin{tabular}{ccc}
\hline Kategori & Norma & Interval \\
\hline Sangat Rendah & $\mathrm{X} \leq \mu-1,5 \mathrm{SD}$ & $22-39$ \\
Rendah & $\mu-1,5 \mathrm{SD}<\mathrm{X} \leq \mu-0,5 \mathrm{SD}$ & $40-50$ \\
Sedang & $\mu-0,5 \mathrm{SD}<\mathrm{X} \leq \mu+0,5 \mathrm{SD}$ & $51-60$ \\
Tinggi & $\mu+0,5 \mathrm{SD}<\mathrm{X} \leq \mu+1,5 \mathrm{SD}$ & $61-70$ \\
Sangat Tinggi & $\mathrm{X}>\mu+1,5 \mathrm{SD}$ & $72-88$ \\
\hline
\end{tabular}

Keterangan $: \mu \quad=$ mean

$\mathrm{SD}=$ standar deviasi

Pada skala perilaku memaafkan terdapat 22 aitem dengan skor 1-4, sehingga nilai terendah (minimal) adalah $1 \times 22=22$, sedangkan nilai tertinggi (maksimal) adalah $4 \times 22=88$, rangenya adalah $88-22=44$, meannya ada- lah $(88+22): 2=55$, dan standar deviasinya adalah $(88-22): 6=11$. Berikut dinamika perubahan skor perilaku memaafkan subjek pada pengukuran prates-pascates: 
Tabel 2. Dinamika Skor Perilaku memaafkan Prates-Pascates

\begin{tabular}{ccccccc}
\hline Inisial & Kelompok & $\begin{array}{c}\text { Skor } \\
\text { Prates }\end{array}$ & kategori & $\begin{array}{c}\text { Skor } \\
\text { Pascates }\end{array}$ & kategori & keterangan \\
\hline AR & & 45 & Rendah & 50 & Rendah & Meningkat \\
SH & & 43 & Rendah & 49 & Rendah & Meningkat \\
MS & & 44 & Rendah & 49 & Rendah & Meningkat \\
N & Kelompok & 58 & Sedang & 60 & Sedang & Meningkat \\
IH & Eksperimen & 70 & tinggi & 76 & Sangat tinggi & Meningkat \\
RH & & 55 & Sedang & 69 & Tinggi & Meningkat \\
RWE & & 79 & Tinggi & 70 & Tinggi & Menurun \\
SS & & 58 & Sedang & 71 & Tinggi & Meningkat \\
\hline OES & & 60 & Sedang & 61 & Tinggi & Meningkat \\
IP & & 65 & Tinggi & 59 & Sedang & Menurun \\
RK & & 48 & Rendah & 53 & Sedang & Meningkat \\
NP & Kelompok & 56 & Sedang & 53 & Sedang & Menurun \\
PRA & Kontrol & 51 & Sedang & 48 & Rendah & Menurun \\
SPO & & 61 & Tinggi & 55 & Sedang & Menurun \\
RN & & 54 & Sedang & 55 & Sedang & Meningkat \\
LN & & 62 & Tinggi & 59 & Sedang & Menurun \\
\hline
\end{tabular}

Berdasarkan hasil prates-pascates pada tabel 2 terlihat bahwa dari 8 orang subjek kelompok eksperimen terdapat 7 orang mengalami peningkatan skor perilaku memaafkan, yaitu $\mathrm{AR}, \mathrm{SH}, \mathrm{MS}$, $\mathrm{N}, \mathrm{IH}, \mathrm{RH}, \quad \mathrm{SS}$ dan terdapat 1 orang yang mengalami penurunan skor perilaku memaafkan yaitu RWE. Pada kelompok kontrol terdapat 3 orang subjek yang mengalami peningkatan skor perilaku memaafkan, yaitu OES, RK, RN dan terdapat 5 orang yang mengalami penurunan skor perilaku memaafkan, yaitu IP, NP, PRA, SPO, dan LN.

\section{Hasil Uji Hipotesis}

Perbedaan perilaku memaafkan dari kelompok eksperimen dan kelompok kontrol dapat terlihat dari hasil uji beda wilcoxon signed rank test. Pada kelompok eksperimen didapat nilai signifikansi (one-tailed) sebesar 0,046 $(p<0,05)$ yang artinya terdapat perbedaan perilaku memaafkan pada subjek antara sebelum dan sesudah diberi 
perlakuan. Sedangkan pada kelom-pok kontrol didapat nilai signifikansi (onetailed) sebesar 0,102 ( $(\mathrm{p}>0,05)$ yang artinya tidak terdapat perbedaan perilaku memaafkan pada subjek antara prates dan pascates.

Analisis data yang digunakan dalam penelitian ini adalah analisis statistik non parametrik mann whitney $u$ test. Mann-Whitney $U$ Test adalah analisis statistik non parametrik untuk membandingkan dua kelompok yang berbeda dengan kondisi pengukuran yang berbeda, serta melihat signifikansi rerata perbedaan peringkat posisi dari dua kelompok (Field, 2009). Sumber data untuk analisis didapatkan melalui gain score. Gain score diperoleh dari selisih hasil antara skor pascates dengan prates. Gain score yang diinput ke dalam SPSS adalah gain score kedua kelompok.

Berdasarkan uji hipotesis mann whitney $u$ test diperoleh hasil signifikansi (two tailed) sebesar 0,020. Penelitian ini menggunakan pengujian satu sisi (one-tailed). Field (2009) mengatakan bahwa jika menggunakan pengujian one-tailed maka nilai signifikansinya dibagi 2. Berdasarkan hasil dari perhitungan Mann-Whitney Test, nilai Z yang diperoleh sebesar -2.329 dengan $\mathrm{p}$ value Asymp. Sig 2 tailed 0,020 (Sig $0,020: 2=0,01$ ) sehingga menjadi 0,01 yang berarti $p<0,05$ artinya hipotesis penelitian ini diterima. Hal ini menunjukkan bahwa ada pengaruh Empathy Care Training untuk meningkatkan perilaku memaafkan pada remaja akhir.

\section{PEMBAHASAN}

Berdasarkan analisis Mann-Whitney $U$ Test, ada pengaruh empathy care training dalam meningkatkan perilaku memaafkan pada remaja akhir. Empathy care training memberikan pengaruh positif bagi subjek untuk meningkatkan perilaku memaafkan. Empathy care training dapat melatih subjek memahami perasaan orang lain dan memandang dari sudut pandang orang lain serta menempatkan diri di posisi orang lain. Kemampuan empati dapat membantu subjek untuk memaafkan atau berdamai dengan individu yang telah menyakiti yang akan berdampak pada kesejahteraan psikologis. Hal ini didukung oleh hasil penelitian Norton (2009) bahwa empati merupakan salah satu konstruk prososial, yang apabila terjadi peningkatan pada empati akan berdampak pada peningkatan pemaafan. Dalam empathy care training individu diberikan pelatihan yang akan menumbuhkan kemampuan empati. Kemampuan empati pada 
individu tersebut akan berpengaruh terhadap perilaku memaafkan individu. Proses kognitif dan afektif yang ada dalam empati akan berakhir pada proses psikomotorik berupa perilaku memaafkan.

Penelitian Witvliet, Ludwig, dan Van der Laan (2001) memfokuskan pada salah satu aspek empati yang melibatkan kognitif, yaitu perspective taking, empati berpengaruh pada respon memaafkantidak memaafkan atas pengalaman yang menyakitkan bagi seorang individu. Selain itu, Exline (2008) dalam penelitiannya menjelaskan bahwa ketika perspective taking dan empati dalam konteks prososial ada dalam diri individu, empati akan menjadi sebuah faktor yang menyeluruh terhadap pemaafan individu. Dalam penelitian ini, perspective taking berarti memahami apa yang dirasakan orang lain, melibatkan kognitif untuk memikirkan dari sudut pandang orang lain serta membayangkan jika berada di posisi orang lain, jika subjek memiliki keterampilan tersebut akan berpengaruh terhadap subjek untuk memaafkan individu yang telah meyakitinya sekalipun yang menyakitinya adalah teman terdekat atau sahabat. Empathy care training melibatkan empat aspek yang ada dalam empati berdasarkan Davis (1980), yaitu perspec- tive taking, fantasy, empathic concern, dan personal distress di mana empat aspek empati ini melewati proses kognitif dan afektif. Dari proses kognitif dan afektif ini akan berakhir pada proses psikomotorik berupa respon memaafkan. McCullough, Rachal, dan Worthington (1997) mengungkapkan bahwa kognitif dan afektif adalah komponen yang mendasar untuk individu mampu berempati yang akan berdampak pada memaafkan. Proses kognitif diawali dengan aspek empati perspective taking dan fantasy. Perspective taking berarti membayangkan dan menempatkan diri di posisi orang lain, mengambil sudut pandang orang lain secara spontan, memprediksikan dan mengintrepetasikan perilaku orang lain dari apa yang dialami orang lain, kemampuan tersebut melibatkan daya kognisi subjek. Ketika subjek mencoba membayangkan dan menempatkan di posisi orang lain, proses berfikir individu akan berperan. Fantasy juga melibatkan proses kognitif, di mana subjek dituntut untuk memahami perasaan orang lain, memahami apa yang dialami orang lain dengan berfikir walaupun melalui media yang tidak dilihat secara langsung. Kemampuan daya kognitif subjek akan memengaruhi individu untuk melakukan perpective taking dan fantasy. 
Kognitif mengacu bahwa subjek tidak hanya berfikir pertikaian antar sahabat terjadi karena pelaku, tetapi juga dirinya mungkin saja juga dapat menyebakan terjadi retaknya suatu hubungan persahabatan. Setelah berfikir atau melewati proses kognitif, subjek akan mulai menggunakan afek atau perasaan yang berorientasi pada orang lain, dalam aspek empati disebut empathic concern. Setelah subjek mencoba menempatkan diri di posisi orang lain, membayangkan dan memahami perasaan orang lain dengan berfikir akan muncul rasa simpati dalam afek subjek. Afektif mengacu pada subjek mencoba mengerti dan bersimpati dengan teman atau sahabat yang telah menyakitinya. Selain itu subjek juga akan mampu mengelola emosi yang berlebihan terhadap teman atau sahabat yang telah menyakitinya. Hal ini terjadi karena adanya pemahaman dari diri subjek terhadap orang yang telah menyakitinya melalui proses kognitif sehingga subjek dapat memiliki rasa simpati dan mengelola emosi terhadap teman atau sahabat yang telah mengecewakan atau mengkhianati.

Kemampuan empati melalui proses kognitif dan afektif akan mendorong subjek untuk dapat memaafkan. Munculnya perilaku memaafkan pada subjek dimulai dari subjek berfikir tentang kesalahan teman atau sahabatnya, memahami perasaan teman yang bersalah, bersimpati kepada teman atau sahabat serta mampu mengelola emosi terhadap teman atau sahabat. Tentu saja proses tersebut adalah bagian dari proses meningkatkan empati. Adanya peningkatan kemampuan empati pada subjek akan berdampak pada peningkatan perilaku memaafkan pada subjek. Hal ini didorong oleh hasil penelitian Tai Mui (2002) yang menunjukkan bahwa ketika individu mendapatkan penjelasan terhadap kesalahan-kesalahan orang lain yang berbuat salah, maka emosi negatif individu akan berubah menjadi rasa prihatin, sehingga individu akan mencoba memahami dan berfikiran positif terhadap kesalahan orang lain dan mendorong individu untuk memaafkan orang lain yang telah berbuat salah.

Peningkatan perilaku memaafkan pada subjek terlihat dari skor prates dan pascates. Secara garis besar, subjek yang diberi perlakuan empathy care training mengalami peningkatan perilaku memaafkan. Hal ini karena subjek diberi perlakuan berupa pelatihan meningkatkan empati yang berdampak meningkatnya perilaku memaafkan pada subjek. Peningkatan perilaku memaafkan terlihat 
dari peningkatan hasil pascates, terdapat peningkatan rerata sebesar 5,25.

Pada kelompok kontrol, meskipun tidak diberi perlakuan dari delapan orang subjek terdapat tiga orang yang mengalami peningkatan perilaku memaafkan yang ditunjukkan melalui hasil skor pascates. Namun, secara keseluruhan dan hasil rerata prates-pascates kelompok kontrol mengalami penurunan.

Peningkatan skor perilaku memaafkan dapat dilihat dari hasil pengukuran pascates. Dengan melihat perbandingan hasil mean prates dan pascates bahwa mean hasil pascates lebih tinggi dari prates ini membuktikan bahwa empathy care training dapat meningkatkan perilaku memaafkan pada subjek. Hal ini berarti peningkatan empati dapat pula meningkatkan perilaku memaafkan pada subjek. Sementara itu, peningkatan empati dapat terlihat dari hasil rangkuman evaluasi, lembar kerja subjek, dan analisis deskriptif catatan lapangan.

\section{SIMPULAN DAN SARAN}

\section{Simpulan}

Berdasarkan hasil penelitian yang telah dilakukan dapat disimpulkan bahwa empathy care training dapat meningkatkan perilaku memaafkan pada remaja akhir. Peningkatan skor perilaku memaafkan terlihat dari pengukuran akhir yaitu pascates serta signifkansi dari analisis data yang yang dilakukan.

\section{Saran}

Ada sejumlah saran yang dapat diberikan. Pertama: saran untuk remaja akhir. Setelah mengikuti pelatihan ini diharapkan pada remaja akhir agar dapat meningkatkan kemampuan empati dengan cara-cara seperti meningkatkan kepedulian serta mampu menerima dan memahami kesalahan individu lain. Harapannya jika suatu saat kembali mengalami peristiwa yang menyakitkan oleh teman atau sahabat, subjek mampu memaafkan dengan tulus karena mengambil dan berfikir dari sudut pandang orang lain dapat membantu untuk memaafkan.

Kedua: saran untuk instansi pendidikan dan Psikolog. Instansi pendidikan diharapkan dapat bekerja sama dengan Psikolog agar dapat memberikan pelatihan meningkatkan empati, karena mahasiswa yang berada pada rentang usia remaja akhir sangat rentan dengan pengalaman yang menyakitkan, sehingga jika remaja merasakan pengalaman yang menyakitkan dengan teman sebaya dapat mengatasi dan menyelesaikan konflik teman sebaya dengan memaafkan. 
Ketiga: saran bagi peneliti selanjutnya. Bagi peneliti selanjutnya ada bebarapa saran yang diajukan terkait penelitian ini. (a) Peneliti harus lebih mengerti mengenai prosedur dalam penelitian eksperimen. (b) Bagi peneliti selanjutnya disarankan sebaiknya dapat melakukan kontrol yang lebih ketat lagi terhadap kemungkinan variabel extronous yang muncul yang dapat mengganggu pelaksanaan pelatihan. (c) Bagi peneliti selanjutya disarankan untuk melakukan screening observer untuk melihat kesetaraan observer dalam mengamati dan menilai perilaku subjek ketika dilaksanakannya eksperimen dengan melakukan inter rater sesama observer untuk menguji reliabilitas obervasi sehingga seluruh observer memiliki persepsi yang sama terhadap perilaku yang diamati.

\section{DAFTAR PUSTAKA}

American Psychological Asociation. (2006). A Handbook forgiveness a sampling of research result. Washington DC: Author.

Asih, G.Y., Pratiwi, M.M.S. (2010). Perilaku prososial ditinjau dari empati dan kematangan emosi.
Jurnal Psikologi Univesitas Muria Kudus, Vol. 1, No. 1, 33-43

Carre, A., Stefaniak, N., Richard, C.B., Bensalah, L., \& D'Ambrosio F. (2013). The Basic empathy scale in adults (BES-A): factor structure of a revised form. Psychological Assesment, 25 (3), 679-691.

Davis, M.H. (1980). A Multidimensional approach to individual differences in empathy. Catalog of Selected Documents in Psychology.

Doverspike, W.F. (2001). How to forgive others: A Key to Emotional Health.

Exline, J. J., Baumeister, R. F., Zell, A. L., Kraft, A. J., \& Witvliet, C. V. O. (2008). Not so innocent: Does seeing one's own capability for wrongdoing predict forgiveness? Journal of Personality and Social Psychology, 94(3), abstract.

Field, A. (2009). Discovering statistic using SPSS third edition. London: Sage Publications Ltd.

Hargrave, T.D. (1994). Families and forgiveness: A Theoretical and therapeutic framework. The Family Journal, 2 (4), 339-348. 
Hurlock, E.B. (2011). Psikologi perkembangan suatu pendekatan sepanjang rentang kehidupan. Jakarta: Erlangga.

Http://ichapiiz.blogspot.com/2012/12/tat a-nilai-perawat. Diakses pada tanggal 27 September 2016 pukul 22.46 WIB

Kurniati, N. M. T. (2009). Memaafkan: kaitannya dengan empati dan pengelolaan emosi. Jurnal proceeding PESAT (Psikologi, ekonomi, sastra, arsitektur, dan sipil) Universitas Gunadarma, 3, A16A24.

Latipun (2004). Psikologi eksperimen edisi kedua. Malang: UMM Press

McCullough, M.E., Rachal, K.C., Worthington, E.L. (1997). Interpersonal forgiving in close relationship. Journal of Personality and Social psychology, 73(2), 321336.

Nashori, H. F. (2011). Meningkatkan kualitas hidup dengan pemaafan. UNISIA Jurnal Ilmu-ilmu Sosial, 33, 214-226.

Nashori, H. F. (2012). Pemaafan pada etnis Jawa warga Kota Yogyakarta.
Bandung: Program Doktor Ilmu Psikologi Universitas Padjadjaran.

Nashori, H.F., Iskandar, Z., Setiono, K., \& Siswadi, A.G.P. (2013). Pemaafan pada enis Jawa ditinjau dari faktor-faktor demografi. Jurnal Pemikiran dan Penelitian Psikologi. 18 (2), 119-128.

Norton, L. (2009). The Effects of empathy-building and elevation on forgiveness. Distinguished Major Thesis. University of Virginia

Riess, H., Kelley, J.M., Bailey, R.W., Dunn, E.J., \& Phillips, M. (2011). Empathy training for resident psysicians: A randomized controlled trial of a neuriscience-informed curriculum. Journal of General Internal Medicine, 26 (1)

Tai Mui (2002). Effect of reminding past transgression on forgiveness. In Partial Fulfillment of Thesis in Psychology. The University of Hongkong.

Taufik (2012). Empati pendekatan psikologi sosial. Jakarta: Rajawali Press.

Untari, P. 9 2014). Hubungan antara empati dengan sikap pemaaf pada 
remaja putri yang mengalami kekerasan dalam berpacaran. Ejournal Psikologi.

Witvliet, C. v., Ludwig, T. E., \& Vander Laan, K. L. (2001). Granting forgiveness or harboring grudges: Implications for emotion, physiology, and health. Psychological Science, 12 (2), 117-123. 